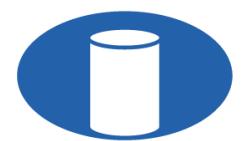

IBRACON Structures and Materials Journal

Revista IBRACON de Estruturas e Materiais

IBRACON

ISSN 1983-4195

ismj.org

ORIGINAL ARTICLE

\title{
Computational and experimental simulation to analyze loss in concrete cover by reinforcement deformation in solid slabs
}

\section{Simulação computacional e experimental para análise de perdas no cobrimento de concreto por deformação da armadura em lajes maciças}

\author{
Ana Paula Maran ${ }^{\mathrm{a}}$ \\ Maria Fernanda Fávero Menna Barreto ${ }^{\mathrm{a}}$ \\ Denise Carpena Coitinho Dal Molin ${ }^{\mathrm{a}}$ (1) \\ João Ricardo Masuero ${ }^{\mathrm{a}}$ (D)
}

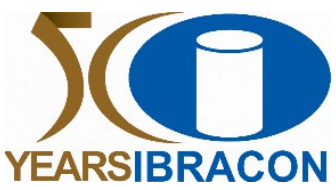

aUniversidade Federal do Rio Grande do Sul - UFRGS, Programa de Pós-graduação em Engenharia Civil - PPGCI, Porto Alegre, RS, Brasil

Received 05 November 2020

Accepted 04 August 2021

\begin{abstract}
Adequate cover thickness contributes to the correct performance of reinforced concrete structures. Spacers are recommended in standards to maintain a concrete cover; however, many regulations do not provide sufficient guidelines for their use, resulting in poor construction. A research program was developed for solid slabs through computational and experimental simulations to minimize errors in the cover by assessing different reinforcement bar diameters and spacer distribution, considering realistic element construction and standards, combining theory with practice. The results show that the use of spacers does not guarantee the design cover for some reinforcement bar diameters, as 4.2 and $5.0 \mathrm{~mm}$, and regardless of the spacer distribution configuration assessed, these meshes undergo permanent deformation, thereby damaging the cover and consequently impact structural performance. Meshes of 6.3 and $8.0 \mathrm{~mm}$ diameters present deformation within the cover tolerance. Therefore, it is preferable to choose bigger diameters and larger mesh spacing to guarantee the projected cover, contributing to the correct performance of the structures, solving one of the major problems in this type of construction.
\end{abstract}

Keywords: cover thickness, concrete cover, spacers, simulation.

Resumo: A espessura de cobrimento adequada contribui para o desempenho das estruturas de concreto armado. Espaçadores são recomendados por normas para obter o cobrimento de concreto, entretanto, muitas dessas normas não fornecem informações suficientes para o uso destes dispositivos, resultando em falhas de construção. O programa deste trabalho foi desenvolvido para lajes maciças através de simulação computacional e experimental, como forma de minimizar erros de cobrimento avaliando diferentes diâmetros de armadura e distribuições de espaçadores, considerando a construção do elemento e as normas vigentes, combinando teoria e prática. Os resultados mostraram que o uso de espaçadores não garante o cobrimento de armadura para algumas malhas de armadura, como 4,2 e 5,0 mm, independentemente da distribuição de espaçadores avaliada, essas malhas sofrem deformação permanente elevada e, consequentemente, impactam no desempenho estrutural. Malhas com barras de diâmetro 6,3 e 8,0 mm apresentaram deformações dentro da tolerância de execução. Assim, é preferível optar pela utilização de malhas mais abertas com diâmetros maiores apara garantir o cobrimento especificado em projeto, contribuindo para o correto desempenho das estruturas, auxiliando um dos maiores problemas neste tipo de construção.

Palavras-chave: espessura de cobrimento, cobrimento de concreto, espaçadores, simulação.

How to cite: A. P. Maran, M. F. F. Menna Barreto, D. C. C. Dal Molin, and J. R. Masuero, "Computational and experimental simulation to analyze loss in concrete cover by reinforcement deformation in solid slabs," Rev. IBRACON Estrut. Mater., vol. 15, no. 2, e15203, 2022, https://doi.org/10.1590/S1983-41952022000200003

Corresponding author: Ana Paula Maran. E-mail: anapaulamaran@gmail.com

Financial support: This work was supported by the Coordenação de Aperfeiçoamento de Pessoal de Nível Superior - CAPES, and the Conselho Nacional de Desenvolvimento Científico e Tecnológico - CNPq. The participation of A. P. Maran was sponsored by CAPES grant number 88882.439894/2019-01; M. F. F. Menna Barreto was sponsored by CNPq grant number 142266/2018-3 and CAPES grant number 88882.439905/2019-01.

Conflict of interest: Nothing to declare. 


\section{INTRODUCTION}

A durable reinforced concrete structure should maintain its original shape, quality, and ease of maintenance when exposed in the environment throughout its projected service life [1]. To protect against aggressive agents, the reinforcement is encased in a concrete cover layer [2], [3], which is defined as the distance between the outer face of the structural member to the nearest bar, including the stirrup and secondary reinforcement [4], [5]. The minimum cover implemented should ensure safe transmission of bond forces, protection of steel bars against corrosion (durability) and adequate fire resistance [6].

The end of the service life of the structure or structural component is associated, among other factors, with the loss of the protection capacity of the concrete cover [3], [7]. Thus, several analysis are developed to predict the effect of the penetration of aggressive agents on the structure, as well as its durability, to assist in prevention strategies [8], [9]. Most models of service-life prediction are correlated with durability and, subsequently, cover.

The cover protection provided is only achieved by the adequate quality of the concrete (composition, production, transport, concreting, thickening, finishing and curing) and sufficient thickness (quality and distribution of the spacers) [10], [11].

The cover thickness specified in the project is related to the environmental aggressiveness class and intended working life, varying according to the standards applied in each country. For reinforced concrete slabs with at least 50 years of service life: in Brazil, nominal standardized covers vary from $20 \mathrm{~mm}$ to $45 \mathrm{~mm}$ [12]; in the U.K., from $25 \mathrm{~mm}$ to $60 \mathrm{~mm}$ [13]; and in the U.S.A., from 20 in to 75 in [4]. Moreover, such covers require a minimum execution tolerance. This tolerance, in standards, is usually related to quality and execution controls [6], [12]-[14], with inspections that include measurements of the cover, and could also be associated with the effective depth of the element [4].

Spacers are used in concrete structures to support the reinforcement and construction loads during construction, so that the required concrete cover is achieved [15], [16]. They are mentioned in the main design and execution standards for reinforced concrete structures [5], [12], [17]-[23], consisting of an essential component that is placed and left permanently in the structure in large quantities [24]-[26]. Despite its importance, limited studies have investigated the effect of spacers on the concrete structures [25], [26].

Some aspects should be considered when choosing the spacer type to be used, such as the product performance [11], the structural element to be concreted, the reinforcement characteristics [10]. Also, the spacer correct quantity and position are essential because the distance between them has a significant influence on the final cover in slabs [27]. Their distribution should consider that an excessive spacing between spacers could cause bars to flex, especially during concreting process. On the other hand, scarce spacer distances promote higher consumption of this material, spending more money, and introducing more points of weakness in the system [15], [25], [26], [28].

For slabs, the normative recommendations indicate a maximum distance of $50 \varnothing$ (50 times the reinforcement diameter) limited to $100 \mathrm{~cm}$ for positive reinforcement, and a maximum distance of $50 \varnothing$ (50 times the reinforcement diameter) limited to $50 \mathrm{~cm}$ for negative reinforcement [17], [19], [29].

Noncompliance in the cover thickness can be related to several factors, such as defects in design and detailing, execution, or materials supply [30]. Such factors interact with one another, so the failure in one could compromise the system [31]. For example, failure to indicate standardized specifications in the project could accumulate successive errors starting from the design stage [32].

Many researchers report the failure to obtain the cover thickness specified in the current reinforced concrete structure constructions [27], [30], [31], [33], [34], where the probability of inefficient cover varies between $38.7 \%$ and $88.8 \%$ in solid slabs [30]. In general, the design reinforcement position is not achieved even before construction [35].

Among the structural elements, the slabs are one of the most damaged elements as a result of insufficient cover thickness [27]. Unsatisfactory covers could be a consequence of uneven placement or insufficient quantity of spacers, lack of formwork leveling [35], [36], spacers with a poor performance [11], wrong choice of spacers, or workers walking through the reinforcement meshes [34]. Furthermore, the minimum cover execution tolerance value of $5 \mathrm{~mm}$, which is related to a good execution quality control, are not met, being directly related to the reduction of building durability [32], [34].

In this context, this study aims to assess the influence of standards' spacers distribution to obtain the concrete cover on solid slabs, considering the reinforcement plastic deformation occurred during the construction. Then, this deformation is compared and its effects are analyzed based on the designed cover thickness. All this, considering concrete construction practices (workers walking over the reinforcement before and during the concrete construction process) and accomplished by combining factors presented in regulatory references. 


\section{METHODS}

To achieve the main goal, a computational simulation was developed to analyze the reinforcement deformation of a solid slab mesh under temporary construction loads. After that, an experimental simulation was performed in a laboratory to validate the computational simulation.

\subsection{Computational simulation}

The simulation was carried out by the Displacement Method.

The slabs were chosen because they are one of the hardest elements to obtain the intended design concrete cover [30] and due to their solid characteristic they are evaluated in a number of studies [30], [32], [34]-[37]. To perform this work, the slabs with $200 \times 200 \mathrm{~cm}$ dimensions were cast with a reinforcement mesh spacing of $20 \mathrm{~cm}$. This mesh spacing was chosen because it is the largest allowed by standards, and it represents the lower stiffness between the available mesh spacing. Therefore, any mesh with a spacing smaller than $20 \times 20 \mathrm{~cm}$ is stiffer, having a better structural performance against the concrete cover.

The meshes were composed of steel for reinforced concrete with a tensile strength of $500 \mathrm{MPa}$ and $600 \mathrm{MPa}$. The diameters of the bars were $4.2 \mathrm{~mm}, 5.0 \mathrm{~mm}, 6.3 \mathrm{~mm}$ and $8.0 \mathrm{~mm}$. The $4.2 \mathrm{~mm}$ diameter is permitted in welded meshes and is more common in waffle slabs. This diameter is not typically used in solid slabs, however it was considered in this laboratory investigation because it is allowed by the standard [12]. The other diameters are frequently used in solid slabs [27], [34], [37]-[39] and were chosen for verification in structural design.

The concrete covers varied from 15 to $45 \mathrm{~mm}$ and are typically referenced in standards and used in design for this type of structure.

The construction loads can influence the permanent deformation of the steel bars, affecting the projected cover thickness due to direct contact with the reinforcement. A load of $1 \mathrm{kN}$ was considered, representing a variable construction load, equivalent to the weight of a person plus tools [40], distributed evenly by reinforcement bar surface and idealized as a rectangle of $10 \times 30 \mathrm{~cm}$, representing a step of a worker walking on top of the reinforcement during the concrete construction process (Figure 1).

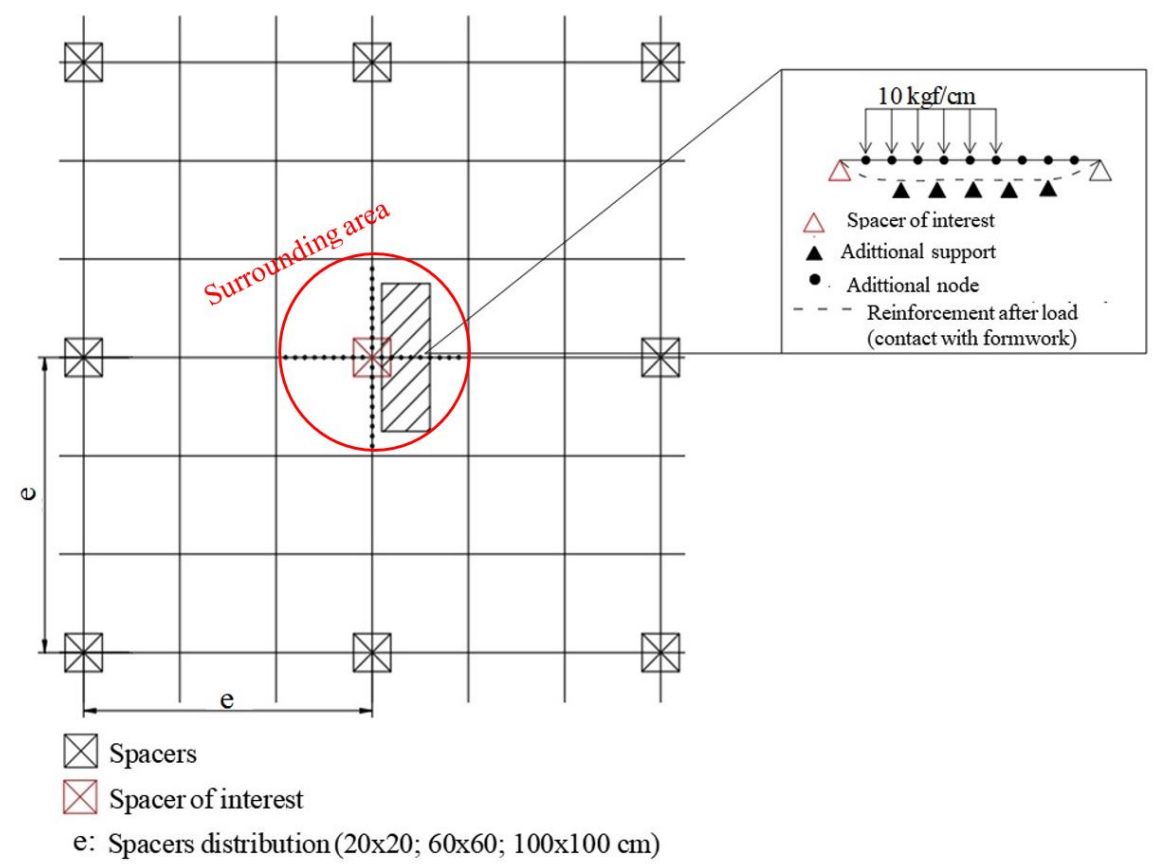

Figure 1. Load application and spacer distribution on the mesh.

Maran [32] simulated the load contribution of the wet concrete weight, and it was not considered in this study because it is minimal $(0.0289 \mathrm{~kg} / \mathrm{cm})$ compared to a worker's weight $(10 \mathrm{~kg} / \mathrm{cm})$. The same author reported that wet concrete weight was not significant due to their involvement and accommodation around the bars and the formwork, acting as a support for the reinforcement. 
The load was applied near the spacer to consider it in only one steel bar (local effect), as a way to simulate the most critical load simulation in a more concentrated form of application. It was applied transversely to the reinforcement, equivalent to a linear load of $10 \mathrm{kgf} / \mathrm{cm}$. The spacers were modeled as a pinned rigid support and their stiffness was not taken into account. The spacer of interest was modeled with displacement restriction in $\mathrm{X}, \mathrm{Y}$ and $\mathrm{Z}$ directions in the mesh plane, while the other spacers had restriction only in the Y direction. The spacer distribution was made based on regulatory guidelines [17], [29]. The cover used for all configurations was $3.0 \mathrm{~cm}$, as it allows a more significant displacement of the bars during the tests.

To perform the simulation, some variables were controlled that directly influence the mesh behavior, listed in Table 1.

Table 1. Variables considered in the simulation.

\begin{tabular}{ccc}
\hline Variables & Levels & Units \\
\hline Mesh opening & 20 & $\mathrm{~cm}$ \\
\hline Steel type & CA 60 and CA 50 & $\mathrm{~mm}$ \\
\hline Reinforcement bar diameter & $4.2 ; 5.0 ; 6.3 ; 8.0$ & 10 \\
\hline Load & $500 ;$ Medium; 100 & $\mathrm{kgf} / \mathrm{cm}$ \\
\hline Standard spacer distribution & $20 \times 20 ; 60 \times 60 ; 100 \times 100$ & $\mathrm{~cm}$ \\
\hline Distribution of spacers & $15 ; 20 ; 25 ; 30 ; 35 ; 40 ; 45$ & $\mathrm{~mm}$ \\
\hline Cover thickness &
\end{tabular}

The reinforcement mesh modeled considers a rigid union between the bars, with a coupling between torsion and bending. Nevertheless, the meshes were composed of independent steel bars with only one coupling against the vertical displacements due to the tying. To adjust this characteristic, the bar's torsional stiffness was reduced to a value close to zero. In the computer simulation, the load and displacement analysis was applied only to the lower bar of the mesh. The analyzed cover thickness included the nominal cover and the minimum cover (reduced permissible execution tolerances), to map the behavior of the mesh with the contact with the formwork.

The reinforcement mesh was modeled with nodes in the bar junctions. In the surrounding area of the central spacer, the analyzed reinforcement bars were modeled with segments of $2 \mathrm{~cm}$ as additional nodes, allowing, through links in these nodes, the simulation of additional formwork supports when the bar comes into contact with it (Figure 1).

If the displacement is less than the cover thickness, it means that the reinforcement does not lean against the formwork. Otherwise, if the displacement is more than the cover thickness, the steel bar leans against the formwork providing additional support and modifying the moments. As a solution, other additional supports with a prescribed displacement equal to the cover were added through iterative method update, simulating the contact of the reinforcement and the formwork.

The analysis was based on the bending moment generated by the construction load and its deformation, according to Figure 2 adopted for computational analysis.

When the bending moment is higher than the limit, it represents the plastification of the reinforcement, permanent deformations, and therefore, reduction of the design cover. The calculations of plastification moments of the bars were generated as a function of the diameter, through Equation 1 (moment of initial plastification) and Equation 2 (moment of total plastification).

$$
\begin{aligned}
& M_{P I}=\left(\frac{\pi R^{3}}{4}\right) \cdot \sigma_{e} \\
& M_{P T}=\left(\frac{4 R^{3}}{3}\right) \cdot \sigma_{e}
\end{aligned}
$$

Where: $\mathrm{M}_{\mathrm{PI}}=$ initial plastification moment $(\mathrm{kN} . \mathrm{cm}) ; R=$ radius of the steel bar $(\mathrm{cm}) ; \sigma_{e}=$ steel yield strength $\left(\mathrm{kN} / \mathrm{cm}^{2}\right)$; $M_{P T}=$ total plastification moment (kN.cm).

The positive and negative bending moments obtained in the simulation were compared with the bending moments of the bar plastification (Table 2). 


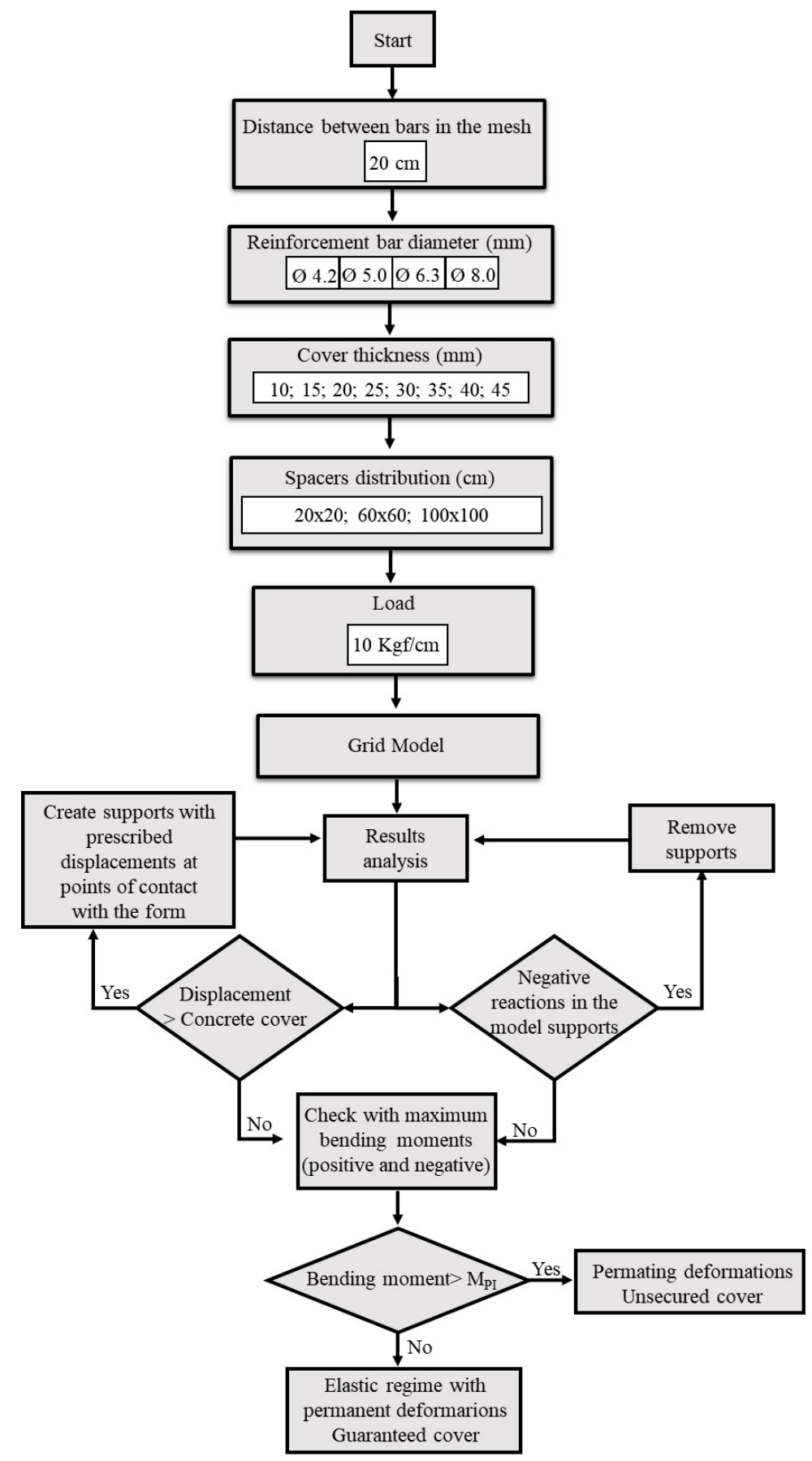

Figure 2. Simulation flowchart.

Table 2. Moment of plastification as a function of the reinforcement bar diameter.

\begin{tabular}{ccc}
\hline \multirow{2}{*}{ Reinforcement bar } & \multicolumn{2}{c}{ Bending moment (kN.cm) } \\
\cline { 2 - 3 } & MPI $^{\text {MPT }}$ \\
\hline (CA 60) Ø 4.2 & 43.64 & 74.09 \\
\hline (CA 60) Ø 5.0 & 73.63 & 125.0 \\
\hline (CA 50) Ø 6.3 & 122.74 & 208.37 \\
\hline (CA 50) Ø 8.0 & 251.33 & 426.67 \\
\hline
\end{tabular}

Note: $\mathrm{M}_{\mathrm{PI}}=$ Moment of initial plastification; $\mathrm{M}_{\mathrm{PT}}=$ Moment of total plastification. 
The initial plastification moment $\left(\mathrm{M}_{\mathrm{PI}}\right)$ indicates when the permanent deformation begins. Bending moments were accepted below $\mathrm{M}_{\mathrm{PI}}$, as the deformation reverses after removing the load, since the deformation is elastic.

The total plastification moment $\left(\mathrm{M}_{\mathrm{PT}}\right)$ defines the reinforcement resistance limit, i.e., the maximum value that the bar can support, behaving like a plastic hinge for increasing loads.

The representative diagrams of the initial and total plastification bending moments are shown in Figure 3 .

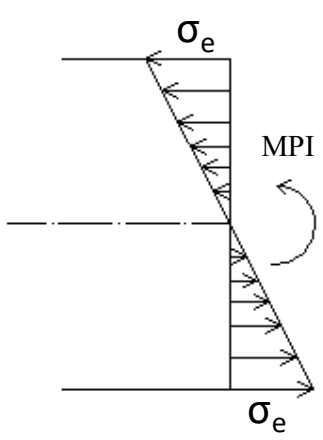

a)

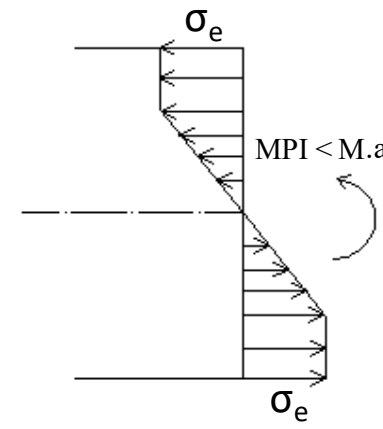

b)

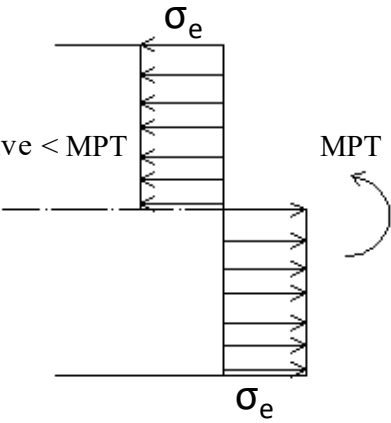

c)

Figure 3. Stress distribution in the cross-section of the bar: a) initial plastification moment;

b) partial plastification moment; c) total plastification moment.

The computational simulation analysis was performed by the linear elastic regime, which allows the identification of permanent deformations, but not their magnitude. Thus, critical values of bending moments for the plastification of the steel bars were experimentally tested in the laboratory to validate the simulation results.

\subsection{Experimental simulation}

The experimental simulation is complementary to the computational simulation since this did not present values for the deformation of the bars, and consequently, the reduction of the cover, being restricted to the supply of the bending moment generated for comparison with the deformation moments. In addition, the experimental simulation was developed to validate the results of the computational simulation.

Reinforcement meshes with $200 \times 200 \mathrm{~cm}$ dimensions, $20 \mathrm{~cm}$ opening, diameters varying from $4.2 \mathrm{~mm}$ to $8.0 \mathrm{~mm}$, with spacer distribution of $20 \mathrm{~cm}, 60 \mathrm{~cm}$ and $100 \mathrm{~cm}$, concrete cover of $3 \mathrm{~cm}$ (intermediate evaluation thickness), and tied in bars intersection with nylon clamps (facility of execution and replacement of steel bars) were reproduced in the laboratory. The load was the same one used in the simulations $(1 \mathrm{kN})$, replicated as a worker steps on the reinforcement. For that, the worker weight was measured and complemented with tools until reaches the test load $(1 \mathrm{kN})$. The foot was measured to confirm the $10 \mathrm{~cm}$ of local load application. This situation was represented in Figure 4. The cover was measured before and after the worker step with a pachymeter along the bar, in each additional nodes represented in Figure 1 and Figure $4 \mathrm{~b}$.

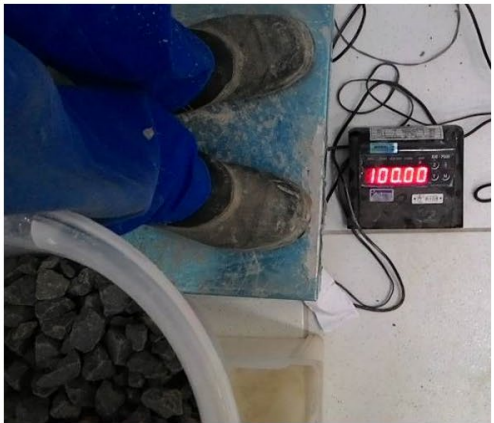

a)

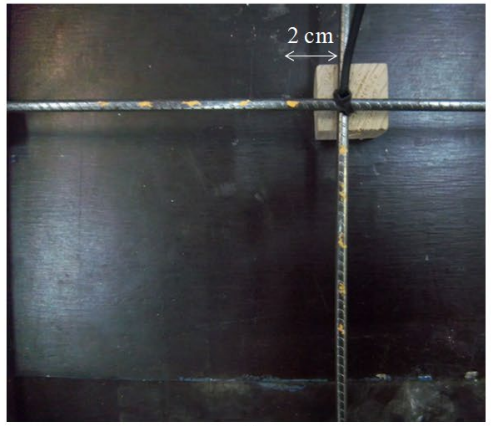

b)

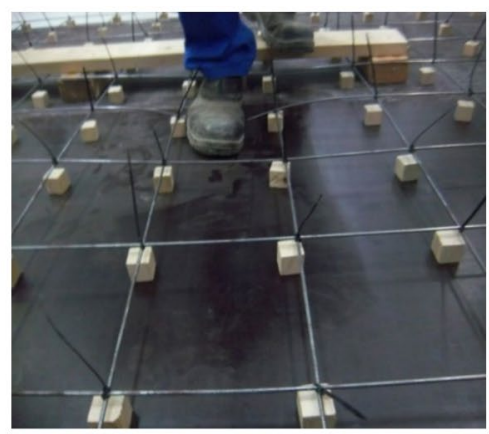

c)

Figure 4. Experimental simulation: (a) load calibration; (b) additional node; (c) deformation caused by loading application. 
The load application and displacement analysis of the bar were done in the center of the mesh (spacer of interest), considering that this reinforcement had a $30 \mathrm{~mm}$ cover (lower bar) and the mesh's upper bar had a cover of $30 \mathrm{~mm}$ more the bar diameter $(30 \mathrm{~mm}+\varnothing)$.

The test was directed to the two bars located at the central point. The application of the load was performed through predetermined points where each central reinforcement bar received only one load application, and then it was changed to another. For each configuration, three exchanges of central reinforcement bars were done.

\section{RESULTS AND DISCUSSIONS}

\subsection{Computational simulation}

The results of the computational simulations were compared with the initial and total plastification moment of the steel bar (Table 2). The effects of the construction load on the bars, relating to the worker walking on the reinforcement mesh with a $20 \mathrm{~cm}$ opening, are shown in Figure 5.

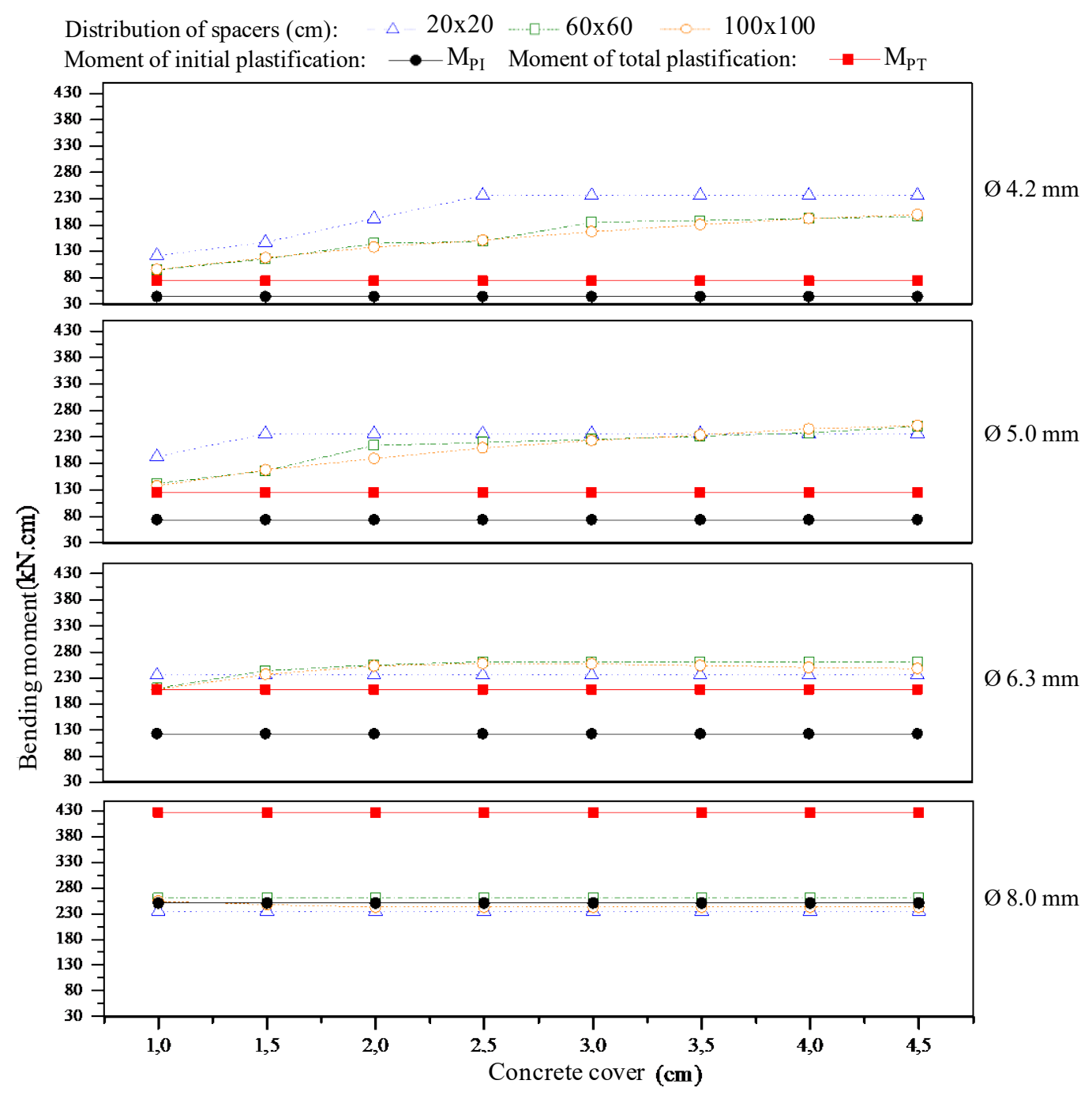

Figure 5. Behavior of the meshes with accidental loading. 
Table 3 presents the comparison between reinforcement displacement (d) and concrete cover (c) to inform the formwork contact. The configurations that resulted in displacement greater than the cover mean the contact of the steel bar with the formwork. The meshes with $8.0 \mathrm{~mm}$ bar diameter did not come into contact with the formwork, regardless of the configuration, due to the stiffness of the reinforcement.

Table 3. Comparison between reinforcement displacement (d) and concrete cover (c).

\begin{tabular}{|c|c|c|c|c|c|c|c|c|c|}
\hline \multirow{2}{*}{$\begin{array}{l}\text { Reinforcement bar } \\
\text { diameter }(\mathbf{m m})\end{array}$} & \multirow{2}{*}{$\begin{array}{c}\text { Spacer } \\
\text { distribution }(\mathbf{c m})\end{array}$} & \multicolumn{8}{|c|}{ Concrete cover $(\mathrm{cm})$} \\
\hline & & 1 & 1.5 & 2 & 2.5 & 3 & 3.5 & 4 & 4.5 \\
\hline \multirow{3}{*}{4.2} & $20 \times 20$ & $d>c$ & $d>c$ & $d>c$ & $d>c$ & $d>c$ & $d>c$ & $d>c$ & $\mathrm{~d}>\mathrm{c}$ \\
\hline & $60 \times 60$ & $d>c$ & $d>c$ & $d>c$ & $d>c$ & $d>c$ & $d>c$ & $d>c$ & $\mathrm{~d}>\mathrm{c}$ \\
\hline & $100 \times 100$ & $d>c$ & $d>c$ & $d>c$ & $d>c$ & $d>c$ & $d>c$ & $d>c$ & $\mathrm{~d}>\mathrm{c}$ \\
\hline \multirow{3}{*}{5.0} & $20 \times 20$ & $d>c$ & $\mathrm{~d}<\mathrm{c}$ & $\mathrm{d}<\mathrm{c}$ & $\mathrm{d}<\mathrm{c}$ & $\mathrm{d}<\mathrm{c}$ & $\mathrm{d}<\mathrm{c}$ & $\mathrm{d}<\mathrm{c}$ & $\mathrm{d}<\mathrm{c}$ \\
\hline & $60 \times 60$ & $d>c$ & $d>c$ & $d>c$ & $d>c$ & $d>c$ & $d>c$ & $d>c$ & $\mathrm{~d}>\mathrm{c}$ \\
\hline & $100 \times 100$ & $d>c$ & $d>c$ & $d>c$ & $d>c$ & $d>c$ & $d>c$ & $d>c$ & $d>c$ \\
\hline \multirow{3}{*}{6.3} & $20 \times 20$ & $\mathrm{~d}<\mathrm{c}$ & $\mathrm{d}<\mathrm{c}$ & $\mathrm{d}<\mathrm{c}$ & $\mathrm{d}<\mathrm{c}$ & $\mathrm{d}<\mathrm{c}$ & $\mathrm{d}<\mathrm{c}$ & $\mathrm{d}<\mathrm{c}$ & $\mathrm{d}<\mathrm{c}$ \\
\hline & $60 \times 60$ & $d>c$ & $d>c$ & $d>c$ & $\mathrm{~d}<\mathrm{c}$ & $\mathrm{d}<\mathrm{c}$ & $\mathrm{d}<\mathrm{c}$ & $\mathrm{d}<\mathrm{c}$ & $\mathrm{d}<\mathrm{c}$ \\
\hline & $100 \times 100$ & $d>c$ & $d>c$ & $d>c$ & $d>c$ & $d>c$ & $d>c$ & $d>c$ & $\mathrm{~d}>\mathrm{c}$ \\
\hline \multirow{3}{*}{8.0} & $20 \times 20$ & $\mathrm{~d}<\mathrm{c}$ & $\mathrm{d}<\mathrm{c}$ & $\mathrm{d}<\mathrm{c}$ & $\mathrm{d}<\mathrm{c}$ & $\mathrm{d}<\mathrm{c}$ & $\mathrm{d}<\mathrm{c}$ & $\mathrm{d}<\mathrm{c}$ & $\mathrm{d}<\mathrm{c}$ \\
\hline & $60 \times 60$ & $\mathrm{~d}<\mathrm{c}$ & $\mathrm{d}<\mathrm{c}$ & $\mathrm{d}<\mathrm{c}$ & $\mathrm{d}<\mathrm{c}$ & $\mathrm{d}<\mathrm{c}$ & $\mathrm{d}<\mathrm{c}$ & $\mathrm{d}<\mathrm{c}$ & $\mathrm{d}<\mathrm{c}$ \\
\hline & $100 \times 100$ & $\mathrm{~d}<\mathrm{c}$ & $\mathrm{d}<\mathrm{c}$ & $\mathrm{d}<\mathrm{c}$ & $\mathrm{d}<\mathrm{c}$ & $\mathrm{d}<\mathrm{c}$ & $\mathrm{d}<\mathrm{c}$ & $\mathrm{d}<\mathrm{c}$ & $\mathrm{d}<\mathrm{c}$ \\
\hline $\mathrm{d}<\mathrm{c}$ & \multicolumn{9}{|c|}{ No contact with formwork } \\
\hline$d>c$ & \multicolumn{9}{|c|}{ Contact with formwork } \\
\hline
\end{tabular}

The meshes with smaller diameters (Ø 4.2, Ø 5.0), irrespective of the distribution of spacers or cover thickness, have a permanent deformation, as the bending moment generated from the application of the load is higher than the initial plastification moment and the total plastification moment calculated.

For an intermediate mesh diameter (Ø 6.3), the bending moment of the bars is close to the total plastification moment of the reinforcement but still higher. That is, there is a decrease in cover caused by the plastic deformation of the bar. However, this deformation is smaller compared to 4.0 and $5.0 \mathrm{~mm}$ diameters bars.

For the reinforcement with larger diameter assessed (Ø 8.0), an elastic behavior occurs with a plastification start, but all simulated configurations present bending moments much lower than the moment of total plastification, which did not happen with the meshes of the others diameters analyzed. No larger diameters were assessed than those presented in this study, probably because their behavior would be better than $\varnothing$ 8.0.

In the smaller diameter bars ( moments, indicating that the permanent deformation of the reinforcement occurs in a generalized way, making it impossible to obtain the specified cover.

\subsection{Experimental simulation}

The initial reinforcement cover, measured before the load application, is presented in Table 4.

Table 4. Initial cover thickness in experimental simulation.

\begin{tabular}{|c|c|c|c|c|}
\hline \multirow{2}{*}{ Spacer distribution (cm) } & \multicolumn{4}{|c|}{ Medium concrete cover (mm) } \\
\hline & $\varnothing 4.2 \mathrm{~mm}$ & $\varnothing 5.0 \mathrm{~mm}$ & $\varnothing 6.3 \mathrm{~mm}$ & $\varnothing 8.0 \mathrm{~mm}$ \\
\hline $20 \times 20$ & 30.21 & 30.24 & 30.56 & 30.85 \\
\hline $60 \times 60$ & 30.50 & 30.13 & 31.12 & 30.02 \\
\hline $100 \times 100$ & 29.42 & 29.88 & 30.30 & 30.22 \\
\hline
\end{tabular}

After the load application, the reinforcement plastic deformations were measured. The plastic deformation was defined by the difference between the initial cover (bar without any load) and cover after application and removal load (residual deformation). The maximum displacement (Max.), which is the bigger plastic deformation between the 
measured points, the mean (Mean), standard deviation (SD), and coefficient of variation (COV), for each bar, with a different diameter measured, are presented in Table 5.

Table 5. Permanent displacement values in experimental simulation.

\begin{tabular}{|c|c|c|c|c|c|c|c|c|c|c|c|c|}
\hline \multicolumn{13}{|c|}{ Permanent deformation of the steel bar ( $\mathrm{mm})$} \\
\hline \multirow{2}{*}{$\frac{\text { Bar diameter }}{\text { Spacer Distribution }(\mathrm{cm})}$} & \multicolumn{3}{|c|}{ Ø $4.2 \mathrm{~mm}(\mathrm{CA}-60)$} & \multicolumn{3}{|c|}{ Ø $5.0 \mathrm{~mm}(\mathrm{CA}-60)$} & \multicolumn{3}{|c|}{ Ø $6.3 \mathrm{~mm}(\mathrm{CA}-50)$} & \multicolumn{3}{|c|}{ Ø $8.0 \mathrm{~mm}(\mathrm{CA}-50)$} \\
\hline & 20 & 60 & 100 & 20 & 60 & 100 & 20 & 60 & 100 & 20 & 60 & 100 \\
\hline Max. $(\mathrm{mm})$ & 11.36 & 7.48 & 5.79 & 8.05 & 6.05 & 5.69 & 1.21 & 1.86 & 1.80 & 0.53 & 1.39 & 1.32 \\
\hline Mean (mm) & 9.62 & 6.77 & 4.98 & 6.29 & 4.75 & 3.79 & 1.17 & 1.42 & 1.44 & 0.42 & 0.96 & 1.14 \\
\hline $\mathrm{SD}$ & 2.08 & 0.63 & 0.71 & 1.52 & 1.24 & 1.65 & 0.06 & 0.43 & 0.31 & 0.16 & 0.51 & 0.16 \\
\hline $\mathrm{COV}$ & 0.22 & 0.09 & 0.14 & 0.24 & 0.26 & 0.44 & 0.05 & 0.30 & 0.22 & 0.39 & 0.53 & 0.14 \\
\hline Formwork contact & Yes & Yes & Yes & No & Yes & Yes & No & No & Yes & No & No & No \\
\hline
\end{tabular}

The reinforcement bars with diameters of $4.2 \mathrm{~mm}$ and $5.0 \mathrm{~mm}$ did not present sufficient stiffness to prevent their contact with the formwork in the application of the accidental load, regardless of the distribution of spacers. It also occurs a reinforcement plastic deformation. Consequently, the bars adjacent to the load application region were lifted, uncoupling the spacer, which generally does not have an adequate fixation, making it even more challenging to obtain the design cover specified.

The meshes with $6.3 \mathrm{~mm}$ bars diameter lean on the formwork for the spacer distribution of $100 \mathrm{~cm}$. Thus, the deformation of the mesh occurs at load application, although, to a lesser extent, compared to meshes with a diameter of $4.2 \mathrm{~mm}$ and $5.0 \mathrm{~mm}$.

The reinforcement bars with $8.0 \mathrm{~mm}$ diameter did not provide contact with the formwork at any spacer's configuration. It was observed during the application of the load that the bars of the mesh perimeter lifted, allowing the displacements of the unfixed spacers.

The experimental simulations were controlled, but the situation found in the constructions is often more unfavorable, such as the deformation of the steel bars before the assembly of the reinforcements, the non-interconnection between all steel bars, the quality of spacers, among others.

\subsection{Computer simulation versus experimental simulation}

The numerical modeling presented the software limitation not to indicate the deformation of the steel bar quantitatively. However, the computer simulation allowed the mapping of critical situations with the indication of the critical bending moment and the formwork contact. Another computational program, which measures the reinforcement deformation, can be future used to compare numerically the experimental deformations obtained.

All observations during the experimental tests about the reinforcement contact with formwork are consistent with the results of the computer simulations. Also, the bending moments generated on the computational analysis are proportional to the displacements achieved in the experimental simulation.

The bars with a diameter of $4.2 \mathrm{~mm}$ showed a more significant deformation than the other meshes investigated, being an expected result due to the small diameter of the steel bar. It was observed that, regardless of the configuration, the bars get in contact with the formwork when the load was applied. This situation also was confirmed by the software.

Another factor that can be observed is that the international regulatory guidelines [17], [29], [41], which determine the minimum spacer distribution of 500, are inefficient, since they do not mention the limitation of the reinforcement diameter used in the project. With this recommendation, the application of loads on the bar causes a positive bending moment with a value above that of the corresponding elastic limit of the material, generating permanent deformations. The formwork acts as a maximum displacement limiter. As the reinforcement, which does not have enough stiffness, the bar leans against the formwork under the action of the load applied, and smaller spacers distribution generates greater curvature and, therefore, a bigger bending moment, as shown in Figure 6.
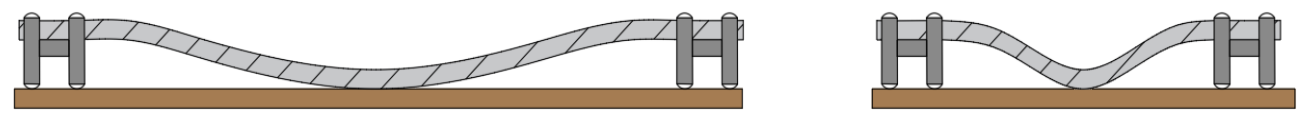

Figure 6. Deformation caused by the same loading at different distances between spacers. 
The deformation caused by the worker single trampled on the reinforcement, for a mesh with $4.2 \mathrm{~mm}$ diameter and $50 \varnothing$ spacer distribution, is much higher than the cover recommended tolerance of $10 \mathrm{~mm}$ in the standards. In turn, meshes of 4.2- and 5.0-mm diameters do not meet the minimum regulatory execution tolerance of $5 \mathrm{~mm}$.

The meshes of diameter $6.3 \mathrm{~mm}$ presented deformations inside the regulatory limit of the cover execution tolerance, in which all values were below $5 \mathrm{~mm}$. Thus, it is possible to state that the reinforcement with a diameter of $6.3 \mathrm{~mm}$, regardless of the distribution of the spacers (until $100 \mathrm{~cm}$ ), fulfills the regulatory guideline, making it possible to guarantee the specified cover thickness.

The deformation, resulting from the load application for the meshes, with a minimum $8.0 \mathrm{~mm}$ diameter bar, were satisfactory, being below the regulatory limit of the cover execution tolerance. Additionally, during the application of the load, the reinforcement had no contact with the formwork, as presented in the computer simulation.

The deformation was analyzed considering only one load application (one worker), however during the structure execution the intense traffic of workers can cause bigger deformations.

Again, the deformation values, obtained in the experimental simulation presented in the distribution of the spacers were consistent with the computational simulation, in which the smaller spacer distribution $(20 \times 20 \mathrm{~cm})$ presents a higher bending moment due to the application of the accidental load compared to the larger spacing $(100 \times 100 \mathrm{~cm})$.

When the bar stiffness is enough to prevent the reinforcement from leaning against the formwork, this results in a the larger spacing between spacers, less curvature, and a smaller moment.

The results indicate that for reinforcement meshes with smaller diameters bars $(4.2 \mathrm{~mm}$ and $5.0 \mathrm{~mm})$, there is no guarantee of the design cover, as they present plastic deformation higher than the minimum recommended execution tolerance $(5.0 \mathrm{~mm})$ in standards, irrespective of the spacers distribution.

This corroborates the situation found in loco by [37], in which slabs with larger reinforcement diameter, under the same conditions, presented a higher probability of meeting the minimum project cover.

As the tests were carried out computationally and laboratory experimentally with meshes with fastening in all nodes, and since this configuration only happens in practice with welded meshes, the deformations under usual execution conditions tend to be higher than those obtained in this study. To obtain the design cover, it is advisable to discontinue the use of reinforcements with these diameters with free traffic of workers on the mesh.

In more critical situations, such as in negative reinforcement, meshes with smaller diameters are very deformable, damaging the cover of the building. Thus, it is preferable to use bars with larger diameters, $8.0 \mathrm{~mm}$ and above to ensure the positioning and rigidity of the reinforcement during concrete construction.

For meshes with an intermediate diameter bar $(6.3 \mathrm{~mm})$, permanent deformations can occur, causing problems if there is no control over the spacers. Therefore, it is advisable to adhere to the international regulatory recommendation that defines the distribution of spacers as $50 \varnothing$ to $100 \mathrm{~cm}$ until studies can corroborate the possibility of using spacings greater than $100 \mathrm{~cm}$.

Finally, for meshes of diameter $8.0 \mathrm{~mm}$ and higher, any spacing of spacers, up to $100 \mathrm{~cm}$, can be used.

\section{CONCLUSIONS}

This study aimed to assess the influence of the spacers distribution to obtain the reinforcement concrete cover of solid slabs, considering some factors that could affect it during the concreting process. The results obtained and the analyses carried out during this study concern solely the sample in question under the evaluated conditions.

The meshes with $4.2 \mathrm{~mm}$ diameter resulted in non-executable scenarios, as they presented deformations that do not exceed the standard cover execution tolerance of $10 \mathrm{~mm}$, while meshes with $5.0 \mathrm{~mm}$ steel bars result in unworkable cover values in works that consider a high execution control, as they present deformation greater than $5 \mathrm{~mm}$, irrespective of the distribution of spacers. In the daily practice of the designer, this means that the adoption of 4.2-mm meshes for slabs is not recommended, and in case of adoption of $5.0 \mathrm{~mm}$ diameter meshes, it is not advisable to reduce the tolerance of the concrete cover.

Although a $4.2 \mathrm{~mm}$ diameter is not common in solid slabs, it is permitted by standard and it is frequently designed for waffle slabs, which are constructed under the same scheme considered in this study. The design of 5.0-mm diameter meshes is very common in solid slabs as it is presented in most studies that investigate concrete covers, usually combined with a concrete cover tolerance reduction. However, mesh with 5.0-mm diameter is permitted by standards, this study proves that its performance is not satisfactory to achieve the concrete cover designed.

The intermediate $6.3 \mathrm{~mm}$ diameter bar showed plastification in the computer simulation, as confirmed in the experimental simulation. Nevertheless, the deformation can be considered within the tolerances of execution, as the obtained deformation were lower than those indicated in standards for the cover tolerances. 
The reinforcement meshes of larger diameters, $8.0 \mathrm{~mm}$ and higher, presented satisfactory performance, because regardless of the distribution spacer configurations the reinforcement does not undergo significant permanent deformation.

When the traffic of workers and equipment are directly on the reinforcement, the existence of the total execution tolerance is crucial. The indicated value for a rigorous cover execution of $5 \mathrm{~mm}$ seems insufficient for the configurations considered for diameters smaller than or equal to $5.0 \mathrm{~mm}$.

In the case of using reinforcement with diameters 4.2 or $5.0 \mathrm{~mm}$, it is preferable to adopt larger diameters with larger mesh spacing, which has an equivalent reinforcement rate. For example, $5.0 \mathrm{~mm}$ diameter meshes with $10 \mathrm{~cm}$ opening are equivalent to $6.3 \mathrm{~mm}$ diameter meshes with $15 \mathrm{~cm}$ opening, so the last mesh cited is preferable to obtaining the concrete cover. In another example, it is preferable to have $8.0-\mathrm{mm}$ meshes with a $20 \mathrm{~cm}$ opening rather than $6.3-\mathrm{mm}$ meshes with a $12.5 \mathrm{~cm}$ opening. Although smaller open meshes were stiffer than the bigger ones, the diameter of the reinforcement is more influential, so the bigger diameters were better to achieve the concrete cover.

These small adoptions can contribute significantly to obtaining the concrete cover, a crucial aspect to structural performance, and it is not achieved in its totality without sudden changes during construction (such as the prohibition of traffic directly on the reinforcement), and thus realistic (yet temporary) construction loads need to be considered.

\section{ACKNOWLEDGEMENTS}

The authors appreciate the financial support of CAPES (Coordenação de Aperfeiçoamento de Pessoal de Nível Superior) and CNPq (Conselho Nacional de Desenvolvimento Tecnológico).

\section{DATA AVAILABILITY STATEMENT}

Some data that support the findings of this study are openly available in Lume Repositório Digital at https://lume.ufrgs.br/handle/10183/127876.

\section{REFERENCES}

[1] American Concrete Institute, "ACI 201 guide to durable concrete: reported by ACI Committee 201," ACI Mater. J., 2008.

[2] B. Aïssoun, K. Khayat, and J.-L. Gallias, "Variations of sorptivity with rheological properties of concrete cover in self-consolidating concrete," Constr. Build. Mater., vol. 113, pp. 113-120, 2016.

[3] R. Wasserman and A. Bentur, "Efficiency of curing technologies: strength and durability," Mater. Struct., vol. 46, no. 11, pp. $1833-1842,2013$.

[4] American Concrete Institute, "ACI 318 building code requirements for structural concrete: reported by ACI Committee 318," ACI Mater. J., 2019.

[5] Associação Brasileira de Normas Técnicas, Execução de Estruturas de Concreto - Procedimento, NBR 14931, 2004.

[6] European Committee for Standardzation, Eurocode 2: Design of Concrete Structures - Part 1.1: General Rules and Rules for Buildings, EN 1992-1.1, 2004

[7] Z. Cui and A. Alipour, "Concrete cover cracking and service life prediction of reinforced concrete structures in corrosive environments," Constr. Build. Mater., vol. 159, pp. 652-671, 2018.

[8] K. Bhargava, A. K. Ghosh, Y. Mori, and S. Ramanujam, "Modeling of time to corrosion-induced cover cracking in reinforced concrete structures," Cement Concr. Res., vol. 35, no. 11, pp. 2203-2218, 2005.

[9] C. Lu, W. Jin, and R. Liu, "Reinforcement corrosion-induced cover cracking and its time prediction for reinforced concrete structures," J. Corros. Sci., vol. 53, no. 4, pp. 1337-1347, 2011.

[10] J. Vaquero, "Separadores para hormigón estructural," Zuncho, no. 13, 2007.

[11] M. F. F. M. Barreto, A. P. Maran, D. C. C. Dal Molin, and J. R. Masuero, "Performance evaluation of plastic spacers: proposal and development of evaluation methods," IBRACON Struct. Mater. J., vol. 9, no. 6, pp. 911-9520, 2016, http://dx.doi.org/10.1590/s198341952016000600006.

[12] Associação Brasileira de Normas Técnicas. Projeto de Estruturas de Concreto - Procedimento, NBR 6118, 2014.

[13] British Standards Institution, Concrete - Complementary British Standard to BS EN 206-1 - Part 1: Method of Specifying and Guidance for the Specifier, BS 8500, 2006.

[14] P. Rougeau and P. Guirard, "Durabilidade do Concreto: Bases Científicas para a Formulação de Concretos Duráveis de Acordo com o Ambiente," G. C. Isaia, Trad., IBRACON, 2014, ch. 7.

[15] F. Muslim; H. S. Wong; N. R. Buenfeld, "The interface bond strength between reinforcement spacer and concrete" in Young Res. Forum IV. Innov. Constr. Mater. (Paper number 19), 2018. 
[16] Concrete Reinforcing Steel Institute, Supports for Reinforcement Used in Concrete, 2016.

[17] España, Instrucción Española del Hormigón Estructural (EHE) EHE 08 - Capítulo XIII - Ejecución, 2008.

[18] Bureau of Indian Standards, Plain and Reinforced Concrete - Code of Practic, IS 456, 2000.

[19] American Concrete Institute, Specifications for Structural Concrete, ACI 301, 2016.

[20] British Standards Institution, Spacers and Chairs for Steel Reinforcement and Their Specification-Part 1: Product Performance Requirements, BS 7973-1, 2001.

[21] Australian Standard, Concrete Structures, AS 3600, 2018.

[22] Japan Society of Civil Engineers, Standard Specification for Concrete Structures, 2007.

[23] New Zealand Standard, Concrete Structures Standard. Part 1 - The Design of Concrete Structures, NZS 3101-1, 2006.

[24] U. M. Angst et al., "The steel: concrete interface," Mater. Struct., vol. 50, no. 143, 2017.

[25] S. Alzyoud, H. S. Wong, and N. R. Buenfeld, "Influence of reinforcement spacers on mass transport properties and durability of concrete structures," Cement Concr. Res., vol. 87, pp. 31-44, 2016, http://dx.doi.org/10.1016/j.cemconres.2016.05.006.

[26] Ø. Strømme, "Influence of cracks and spacers on chloride penetration and reinforcement corrosion in concrete," Norwegian Univ. Sci. Technol., Norwegian, 2017.

[27] A. P. Maran, M. F. F. Menna Barreto, A. B. Rohden, D. C. C. Dal Molin, and J. R. Masuero, "Assessment of cover to reinforcement in slabs using different spacer and tying distances," IBRACON Struct. Mater. J., vol. 8, no. 5, pp. 625-643, 2015.

[28] F. Muslim, Z. Gu, H. S. Wong, and N. R. Buenfeld, "Effect of reinforcement spacers on mass transport properties of concrete containing supplementary cementitious materials," in 36th Cem. Concr. Sci. Conf., Cardiff, 2016.

[29] British Standards Institution, Spacers and Chairs for Steel Reinforcement and Their Specification - Part 2: Fixing and Application of Spacers and Chairs and Tying of Reinforcement, BS 7973, 2001.

[30] M. F. F. Menna Barreto, A. P. Maran, D. C. C. Dal Molin, and J. R. Masuero, Conver to Steel in Reinforced Concrete Structures and Their Spacers. LAMBERT Academic Publishing, 2015, 65 p.

[31] L. A. Clark, M. G. K. Shammas-Toma, D. E. Saymour, P. F. Pallet, and B. K. Marsh, "How can we get the cover we need," Struct. Eng., vol. 75, no. 17, 2007.

[32] A. P. Maran, “Análise da influência da distribuição de espaçadores na garantia da espessura de cobrimento especificada em lajes de concreto armado," M.S. thesis, Univ. Fed. Rio Grande do Sul, Porto Alegre, 2015.

[33] B. Marsh, "Specification and achievement of cover to reinforcement," Adv. Concr. Tech., vol. 1, pp. 1-9, 2003.

[34] V. Palm, A. P. Maran, M. F. F. Menna Barreto, D. C. C. Dal Molin, and J. R. Masuero, "Influência da distribuição de espaçadores no cobrimento e na vida útil de lajes maciças," Ambient. Constr., vol. 20, no. 3, pp. 671-686, 2020.

[35] D. Campos, "Cobrimento de armadura em estruturas de concreto armado: análise comparativa entre valores antes, durante e depois da concretagem," Monograph, Univ. Fed. Rio Grande do Sul, Porto Alegre, 2013.

[36] O. S. P. Silva, "Cobrimento de armadura em estruturas de concreto armado: análise comparativa entre o valor especificado em projeto e o em execução em obras na cidade de Porto Alegre,” Monograph, Univ. Fed. Rio Grande do Sul, Porto Alegre, 2012.

[37] M. F. F. Menna Barreto, A. P. Maran, D. C. C. Dal Molin, J. R. Masuero, and R. Z. Alves, "Influência do diâmetro da armadura no cobrimento final em lajes de concreto armado," in An. 56 Cong. Bras. Concr., 2014.

[38] C. O. Campos, L. M. Trautwein, R. B. Gomes, and G. Melo, "Experimental study of solid RC slabs strengthened on the upper face," IBRACON Struct. Mater. J., vol. 11, no. 2, pp. 255-278, 2018.

[39] F. B. Mendonça, G. S. Urgessa, L. E. N. Almeida, and A. F. F. Rocco, "Damage diagram of blast test results for determining reinforced concrete slab response for varying scaled distance, concrete strength and reinforcement ratio," Eng. Sci., vol. 93, no. 1, e20200511, 2021.

[40] Associação Brasileira de Normas Técnicas, Cargas para o Cálculo de Estruturas de Edificações, NBR 6120, 2019.

[41] Comité Euro-International du Béton, Spacers, Chairs and Tying of Steel Reinforcement, Bulletin d'Information No. $201,1990$.

Author contributions: APM conceptualization, writing, methodology, data curation, formal analysis; MFFMB: writing, methodology, data curation, formal analysis; DCCDM: conceptualization, supervision, methodology; JRM: methodology, formal analysis, supervision.

Editors: Mauricio Pina Ferreira, Guilherme Aris Parsekian. 